\title{
Unpacking the health and social consequences of COVID-19 through a race, migration and gender lens
}

\author{
Josephine Etowa ${ }^{1} \cdot$ llene Hyman ${ }^{2,3,4}$ [D \\ Received: 12 August 2020 / Accepted: 11 November 2020 / Published online: 6 January 2021 \\ (C) The Canadian Public Health Association 2021
}

\begin{abstract}
The ongoing COVID-19 pandemic has emerged as an unprecedented challenge for healthcare systems across the world. To date, there has been little application of a race, migration and gender lens to explore the long-term health and social consequences of COVID-19 in African, Caribbean and Black (ACB) communities in Canada, who have been disproportionately impacted by this pandemic. The evidence presented in this commentary suggests that recovery strategies need to adopt an intersectional lens taking into account race, migration and gender since ACB women and ACB immigrant women have been among the populations most impacted both personally and economically. To do so, there is an urgent need to incorporate variables capturing race, beyond "visible minority" status; gender, beyond looking at differences between women and men; and factors to help understand the complexities of migration trajectories (i.e., beyond the dichotomy of born in Canada versus not born in Canada categories) in Canadian datasets. We provide examples of policy and practice initiatives that will be urgently required to address the needs of these population groups as these race-based data become available.
\end{abstract}

\section{Résumé}

La pandémie de COVID-19 en cours se révèle être un défi sans précédent pour les systèmes de santé du monde entier. Jusqu'à maintenant, on a très peu appliqué le prisme de la race, de la migration et du genre pour explorer les conséquences sociosanitaires à long terme de la COVID-19 dans les communautés africaines, caribéennes et noires (ACN) du Canada, qui ont été démesurément touchées par cette pandémie. Selon les données probantes présentées dans notre commentaire, les stratégies de rétablissement doivent adopter un prisme intersectionnel qui tient compte de la race, de la migration et du genre, car les femmes ACN et les immigrantes ACN sont parmi les populations les plus touchées, personnellement et économiquement. Pour cela, il faut de toute urgence intégrer dans les jeux de données canadiens des variables qui saisissent la race, au-delà du statut de « minorité visible »; le genre, au-delà des différences entre femmes et hommes; et les facteurs qui aident à comprendre les trajectoires de migration dans toute leur complexité (c.-à-d. au-delà de la dichotomie des catégories « né au Canada » et « né à l'étranger »). Nous donnons des exemples d'initiatives stratégiques et pratiques qui seront nécessaires à très court terme pour répondre aux besoins de ces segments démographiques à mesure que les données fondées sur la race deviendront disponibles.

Keywords COVID-19 $\cdot$ Health and social inequities $\cdot$ Race $\cdot$ African, Caribbean, Black populations $\cdot$ Gender $\cdot$ Migration $\cdot$ Health outcomes $\cdot$ Policy $\cdot$ Health practice

Ilene Hyman

i.hyman@utoronto.ca

Josephine Etowa

jetowa@uottawa.ca; http://www.health.uottawa.ca/sn/index.htm

1 School of Nursing, Faculty of Health Sciences, Ontario HIV Treatment Network Chair in Black Women's HIV Prevention and Care, Canadian of African Descent Health Organization (CADHO), University of Ottawa, 451 Smyth Road, Ottawa, ON K1H 8M5, Canada
2 Faculty of Health Sciences, University of Ottawa, Ottawa, Canada

3 Dalla Lana School of Public Health, University of Toronto, Toronto, Canada

4 Graduate Program in Health, York University, Toronto, Canada 
Mots-clés COVID-19 $\cdot$ iniquités sociosanitaires $\cdot$ race $\cdot$ populations africaines, caribéennes, noires $\cdot$ genre $\cdot$ migration $\cdot$ résultats sanitaires · politique (principe) · pratiques en santé

\section{Introduction}

The ongoing COVID-19 pandemic has emerged as an unprecedented challenge for healthcare systems across the world. While it is true that the entire world is affected, health risks, burdens, experiences and outcomes are not the same for everyone. African, Caribbean and Black communities $\left(\mathrm{ACB}^{1}\right)$ represent vulnerable populations in terms of their health risks, receipt of adequate care and chance of recovery. This increased burden of COVID-19 morbidity and mortality translates into greater challenges for healthcare systems through loss of social capital and productive labour force and erosion of cultural equity. Although governments have expedited emergency measures to mitigate the immediate economic impacts of the pandemic, there has been little application of a race, migration and gender lens to explore the long-term health and social consequences of COVID-19 among groups who have been disproportionately impacted.

In Canada, there is widespread recognition that social determinants of health $(\mathrm{SDOH})$ account for the disproportionate health risks and health inequities experienced in the population. The WHO Commission on the SDOH explicitly recognizes racism as a contributor to socio-economic position, a key structural determinant of health. Closer to home, Toronto's Board of Health declared anti-Black racism as a public health crisis. Racism affects people not only at an interpersonal level but also through the broader structures of society, most notably in the systems of education, justice, media, policing, immigration and employment, as well as through hate activity and government policies.

According to Statistics Canada, Canada's ACB population currently accounts for $3.5 \%$ of Canada's total population and $15.6 \%$ of the population defined as a "visible minority" in Canada. The ACB population will continue to increase and could represent between $5.0 \%$ and $5.6 \%$ of Canada's population by 2036 . Furthermore, the ACB population in Canada is not a homogeneous group. In 2016, more than four in $10 \mathrm{ACB}$ people were born in Canada. Other intersecting identities, such as gender, age and religion, shape experiences and impact on health and well-being.

\footnotetext{
${ }^{1}$ The term African, Caribbean and Black (ACB) communities in Canada is often used interchangeably with Black Canadians. This term is increasingly becoming popular, because it captures the heterogeneity (diversity) of Black Canadian subpopulations and is inclusive of all Black people in Canada regardless of their place of origin. The use of this term ensures the inclusion of Black Canadians who emigrated from the continent of Africa, those who emigrated from Caribbean regions, and Black Canadians who have lived in the western world including Canada for multiple generations.
}

Prior to the COVID-19 pandemic, SDOH strongly impacted on the health and well-being of ACB populations. In 2016, $21 \%$ of the ACB population lived in a low-income situation, compared with $12 \%$ of their counterparts in the rest of the population. Approximately one third of the ACB populations were engaged in precarious work, and these proportions were higher among racialized women $(43.1 \%)$ and newcomer women, who are largely racialized $(48.1 \%)$ (Noack and Vosko 2011). The prevalence of everyday discrimination attributed to race was highest among respondents who selfidentified as Black, compared with other groups (30.8\%) (Hyman et al. 2019). Black Canadians were almost twice as likely as White Canadians to report that they were treated badly or with less respect (Siddiqi et al. 2017). Disaggregated by gender, almost $20 \%$ of ACB women compared with $15 \%$ of $\mathrm{ACB}$ men reported experiencing unfair treatment, compared with their non-ACB counterparts (Statistics Canada 2020).

It is thus not surprising that ACB people experience inequities in health outcomes such as hypertension, diabetes, chronic stress and obesity (Di Cesare et al. 2013; Kurian and Cardarelli 2007). Inequities are further pronounced among $\mathrm{ACB}$ women in Canada for whom rates of diabetes and hypertension are escalating (Chiu et al., 2015). ACB women are also vastly overrepresented in new HIV infections in comparison with their White counterparts but have been largely neglected in HIV research and interventions (PHAC 2018). While immigration is not in itself a risk factor, migration trajectories intersect with race, sex, gender and other social determinants of health risks (Vissandjee and Hyman 2020).

Current rates of COVID-19 infection and mortality in the ACB population in Canada are unclear because little race-based data are collected. However, data from the United States indicates that Black populations are tragically overrepresented in morbidity and mortality rates (CDC 2020). In Canada, Public Health Ontario reports indicate that COVID-19 rates are three times higher in areas where there are more racialized people; hospitalization and ICU rates are four times higher; and mortality rates are doubled. According to Toronto Public Health, ACB people comprise only $9 \%$ of the city's overall population yet they make up $21 \%$ of reported COVID-19 cases. Women, who are often unemployed or precariously employed in sectors affected by the pandemic, such as retail and service jobs, have experienced proportionately steeper job losses than men (Statistics Canada 2020). Women also comprise $70 \%$ of health and social service workers, which places them at greater risk of exposure to the virus. In Canada, more than one third of people employed as nurse aides, orderlies and patient service are 
immigrants, and women account for $86 \%$ of this group (Turcotte and Savage 2020).

Pre-existing and current $\mathrm{SDOH}$, including pre-existing structural inequities and discrimination, undoubtedly account for the disproportionate COVID-19 health outcomes experienced in ACB populations. We know from Canadian population surveys that $\mathrm{ACB}$ people have taken an economically hard hit from COVID-19. ACB people exceed 50\% on economic vulnerability arising from the COVID-19 crisis. Approximately $61 \%$ have seen a decrease in their income, $50 \%$ have difficulty meeting their financial obligations and $47 \%$ are unable to pay their mortgage or rent on time (Jedwab 2020).

Crises and times of unrest are also known to be catalysts for gender-based violence due to financial instability, unstable social and protective networks, and the reinforcement of unequal power dynamics, which in turn affect access to necessary health and social supports (Peterman et al. 2020). Paradoxically, in the context of COVID-19, "stay at home" recommendations increase the risk of violence for many women while acting as a barrier to safety and support (Zero and Geary 2020). Approximately $11.7 \%$ of immigrant women compared with $7 \%$ of Canadian-born women report that they are extremely or very concerned about violence in the home during COVID-19 (Hyman and Vissandjee 2020). According to Khanlou and Ssawe (2020), racialized women are experiencing a syndemic of gender-based violence and systemic racism in the context of COVID-19, placing their wellbeing at a disproportionate risk.

COVID-19 is demonstrating itself to be a vector in deepening economic and social inequalities. Governments have acted quickly to mitigate the immediate economic impacts of the pandemic. But as the economy re-opens, less attention has been paid to COVID's long-term health impacts, especially among ACB groups. In a Briefing Note to the Standing Committee on Health, Kwame McKenzie, CEO of the Wellesley Institute notes, "Our current social policies produce health disparities.[...] [R] ecovery needs to focus on those communities that have been hardest hit, particularly our communities of people of African and Caribbean heritage. If we do not want these communities to fall further behind, we need a focused recovery plan." (McKenzie 2020). The evidence presented in this commentary further suggests that recovery strategies need to adopt an intersectional lens taking into account race, migration and gender since ACB women and ACB immigrant women are among the populations most impacted personally and economically by this pandemic. To do so, there is an urgent need to incorporate variables capturing race, beyond "visible minority" status; gender, beyond looking at differences between women and men; and factors to help understand the complexities of migration trajectories (i.e., beyond the dichotomy of born in Canada versus not born in Canada categories) in Canadian datasets.
As these much-needed race-based data become available, they will need to be translated into policy and practice initiatives. Based on available evidence and our collective experiences, we would like to share examples of the types of initiatives urgently needed by ACB communities at this time. These include:

- Policy and governance structures for the ownership and protection of sensitive ACB subpopulation datasets.

- Evidence-based institutional policies and practices aimed at undoing institutional racism (e.g., more representative hiring practices, staff anti-racism training, adopting antiracist and inclusive mission and vision statements).

- Evidence-based interventions aimed at reducing the health consequences of COVID-19 that result from chronic disease risk factors prevalent in the ACB populations (e.g., in the areas of food security, income security, access to physical activity, and access to chronic disease information, treatment and support).

- Evidence-based interventions aimed at addressing SDOH that increase the risk of COVID-19 in ACB communities (e.g., employment and working conditions, housing stability). Return to work policies should include wage increase, especially for many ACB women who are essential workers; improved working conditions (e.g., eliminate precarious work); and provision of benefits (e.g., sick days).

- On-the-ground community-based programming to serve as safety net for the many ACB community members, especially women, who have historically not been able to access culturally responsive care.

- The creation of a sustainable community-based network of peer-led trusted providers who can help ACB women safely access healthcare.

- Services to reduce health risks from COVID-19 among ACB women providing essential services, such as affordable childcare options, broadband Internet services, and respite care where women with COVID-19 who are unable to physically distance safely at home can stay away from family members.

- Services to address the increasing rates of violence experienced by women by improving the quality of and access to coordinated health, police and justice, and social services for women.

The longstanding problems of ACB communities that have been exposed by COVID-19 call for creativity in developing an effective and sustained response. A key ingredient of such response is the meaningful engagement of $\mathrm{ACB}$ women. To ensure the success of policy and practice interventions, $\mathrm{ACB}$ women must be meaningfully engaged in their design, implementation and evaluation processes. ACB women need to be recognized as the "indigenous experts" of their own lived experiences. 


\section{Compliance with ethical standards}

Conflict of interest The authors declare they have no conflict of interest.

\section{References}

Centers for Disease Control and Prevention. (2020). Health equity considerations and racial and ethnic minority groups. Atlanta, GA: US Department of Health and Human Services, Centers for Disease Control and Prevention. Available at: https://www.cdc.gov/ coronavirus/2019-ncov/community/health-equity/race-ethnicity. html.

Chiu, M., Maclagan, L. C., Tu, J. V., et al. (2015). Temporal trends in cardiovascular disease risk factors among white, South Asian, Chinese and black groups in Ontario, Canada, 2001 to 2012: a population-based study. BMJ Open, 5, e007232. https://doi.org/10. 1136/bmjopen-2014-007232.

Di Cesare, M., et al. (2013). Inequalities in non-communicable diseases and effective responses. Lancet, 381(9866), 585-597.

Hyman, I., \& Vissandjee, B. (2020). Covid-19, Intersectionality and Concerns about Violence at Home among Immigrant Men and Women. Canadian Diversity, 17(3), 34-40.

Hyman, I., Ansara, D., Forte, T., O’Campo, P., Finn, D., Siddiqui, A., Smylie, J., \& McKenzie, K. (2019). Prevalence and predictors of everyday discrimination in Canada: findings from a national survey. Toronto: Wellesley Institute Available at: https://www. wellesleyinstitute.com/wp-content/uploads/2019/10/Prevalenceand-Predictors.pdf.

Jedwab, J. (2020). Canadian opinion on the coronavirus - No. 14: economic vulnerability score for selected visible minorities and the effects of COVID-19. Association for Canadian Studies. Retrieved from: https://acs-aec.ca/wp-content/uploads/2020/04/ACS-Covidand-Economic-Vulnerability-of-Visible-Minorities-April-2020-1. pdf.

Khanlou, K. \& Ssawe, A. (2020). COVID-19 pandemic guidelines for mental health support of racialized women at risk of gender-based violence. Knowledge Synthesis Report, July. Retrieved from: https://cihr-irsc.gc.ca/e/documents/KHANLOU-Initial-KnowledgeSynthesis-Report-2020-06-22.pdf $+\& \mathrm{~cd}=1 \& \mathrm{hl}=\mathrm{en} \& \mathrm{ct}=\mathrm{clnk} \& \mathrm{gl}=\mathrm{ca}$.
Kurian, A. K., \& Cardarelli, K. M. (2007). Racial and ethnic differences in cardiovascular disease risk factors: a systematic review. Ethnicity \& Disease, 17(1), 143.

McKenzie, K. (2020). Briefing to Standing Committee on Health: Canada's COVID-19 response. July 7, 2020. Available at: https:// www.wellesleyinstitute.com/briefing-to-standing-committee-onhealth-canadas-covid-19-response/. Accessed 20 Nov 2020.

Noack, A. M., \& Vosko, L. F. (2011). Precarious jobs in Ontario: Mapping dimensions of labour market insecurity by workers' social location and context. Toronto: Law Commission of Ontario.

Peterman, A., Potts, A., O’Donnell, M., Thompson, K., Shah, N., OerteltPrigione, S., \& van Gelder, N. (2020). Pandemics and violence against women and children. Center for Global Development Working Paper, 528.

Public Health Agency of Canada. (2018). Summary: estimates of HIV incidence, prevalence and Canada's progress on meeting the 90-90$90 \mathrm{HIV}$ targets, 2016. Retrieved from: https://www.canada.ca/en/ public-health/services/publications/diseases-conditions/summaryestimates-hiv-incidence-prevalencecanadas-progress-90-90-90. html.

Siddiqi, A., Shahidi, F. V., Ramraj, C., \& Williams, D. R. (2017). Associations between race, discrimination and risk for chronic disease in a population-based sample from Canada. Social Science \& Medicine, 194, 135-141.

Statistics Canada (2020). Labour force survey, Mar 2020. Retrieved from: https://www150.statcan.gc.ca/n1/daily-quotidien/200409/ dq200409a-eng.htm.

Turcotte, M., \& Savage, K. (2020). The contribution of immigrants and population groups designated as visible minorities to nurse aide, orderly and patient service associate occupations. Ottawa: Statistics Canada.

Vissandjee, B., \& Hyman, I. (2020). Immigrant women. In M. Morrow, O. Hankivsky, \& C. Varcoe (Eds.), Women's health in Canada: critical perspectives on theory and policy. Toronto: University of Toronto.

Zero, O., \& Geary, M. (2020). COVID-19 and Intimate Partner Violence: A Call to Action. Rhode Island Medical Journal, 103(5).

Publisher's note Springer Nature remains neutral with regard to jurisdictional claims in published maps and institutional affiliations. 